Article

\title{
Entrepreneurial Leadership, Performance, and Sustainability of Micro-Enterprises in Malaysia
}

\author{
Abdullah Al Mamun 1,*(D), Mohamed Dahlan Ibrahim ${ }^{2}$, Mohd Nor Hakimin Bin Yusoff ${ }^{2}$ \\ and Syed Ali Fazal ${ }^{2}$ (D) \\ 1 Global Entrepreneurship Research and Innovation Centre (GERIC), Universiti Malaysia Kelantan, \\ Kota Bharu, Kelantan 16100, Malaysia \\ 2 Faculty of Entrepreneurship and Business, Universiti Malaysia Kelantan, Kota Bharu, Kelantan 16100, \\ Malaysia; dahlan@umk.edu.my (M.D.I.); hakimin@umk.edu.my (M.N.H.B.Y.); \\ fazalsyedali@gmail.com (S.A.F.) \\ * Correspondence: abdullah.a@umk.edu.my; Tel.: +6-013-300-3630
}

Received: 3 April 2018; Accepted: 14 May 2018; Published: 16 May 2018

\begin{abstract}
This study probed into the impact of entrepreneurial leadership dimensions (i.e., responsibility, accountability, analytical thinking, and emotional intelligence) on the performance and sustainability of micro-enterprises in Kelantan, Malaysia, through the lens of resource-based view (RBV) theory. Through the implementation of a cross-sectional design, data were randomly gathered from 403 micro-entrepreneurs whose names appeared in the list of low-income households registered under "Majlis Amanah Rakyat" Kelantan and "Majlis Agama Islam Dan Adat Istiadat" Kelantan. The quantitative data were collected during structured interview sessions held between September and December 2017. The findings of the study revealed that the aspects of responsibility, accountability, and emotional intelligence exhibited significantly positive effects on micro-enterprise performance; while accountability, analytical thinking, and micro-enterprise performance displayed a significantly positive influence on sustainability among micro-enterprises owned by low-income households in Kelantan, Malaysia. The outcomes further portrayed a significant mediating effect of micro-enterprise performance on the correlations of responsibility, analytical thinking, and emotional intelligence with micro-enterprise sustainability. The outcomes of this study extend the scope of RBV theory and simultaneously enhance our understanding pertaining to leadership, performance, and sustainability interplay, particularly within the context of micro-enterprises in emerging economies. As such, it is recommended that the government of Malaysia formulate and to adopt policies that promote varied entrepreneurial-leadership-related traits among budding micro-entrepreneurs, which may not only boost sustainability performance among firms, but also encourage low-income household heads to actively engage in more entrepreneurial activities.
\end{abstract}

Keywords: entrepreneurial leadership; micro-enterprise performance; sustainability

\section{Introduction}

Intricacies in business, coupled with enhanced global transformation, have impelled firms to be responsible citizens towards realizing sustainability agendas. As a substantial number of firms have amalgamated their affirmative commitment with sustainable business practices into corporate identities, these budding enterprises within the Asia-Pacific region have ample room for improvement [1], particularly in terms of Small and Medium Enterprises (SMEs) that appear to contribute immensely to economies across nations [2]. The significantly positive role played by small and micro-enterprises in eradicating poverty and creating vast employment opportunities, especially among emerging economies, has been highlighted by both policy makers and academics [3,4]. Small and micro-enterprises, which serve as drivers of indigenous entrepreneurship and national development, 
have an essential role at all levels of the global economy by energizing technological capability building, diffusion of innovations, and capital mobilization [5]. As for Malaysia, which reflects an emerging economy, micro-enterprises that account for $75 \%$ of the total number of SMEs employ approximately 1.3 million individuals throughout the nation, hence signifying its essential function in national development [6,7]. Micro or small enterprises differ vastly from the larger conglomerates, as MEs are characterized by one-person-operated, poorly managed, prone to be impermanent, frequently less productive, often informal, and undercapitalized [8] business ventures that have economic activities outside formal institutional limitations, but within informal institutional borders. In addition, micro-enterprises fulfil the demand of the large communal groups by engaging low-paid employees as waged workers, which seems to be extensively popular among low-income and underprivileged communities, thus emerging as a powerful instrument to combat poverty as well as to empower the poor economically $[6,9]$.

Successful and sustainable entrepreneurship demands individuals with unique abilities and personality traits, some of which have been emphasized in the literature to be significantly influential in acquiring varied levels of organizational success [10]. From the stance of micro and small firms, enterprise performance is highly dependent on entrepreneurial characteristics and competencies, such as leadership capabilities, managerial and networking skills, technological abilities, and the education level of entrepreneurs [3,11]. Leadership, as an entrepreneurial behaviour, is important due to its potential in recognizing one's value in the entrepreneurial process; thus, it is considered vital in a variety of organizational-sustainability-related aspects, such as fostering innovation and adapting to changing environments [12]. Entrepreneurial leadership plays a significant role in determining the success of business ventures [13]. As for small businesses, entrepreneurial leadership remains essential as micro-entrepreneurs may not successfully develop their business without displaying effective leadership traits [14]. Perhaps, this may be the reason that the theme of micro-enterprise success has emerged as popular among entrepreneurs and researchers, especially for those keen in discovering a definitive formula for successful micro-entrepreneurship [15].

The above discussion raises two essential unanswered (in the extant literature) questions that have been addressed in this paper, which are: (1) "what are the specific attributes of entrepreneurs (in terms of entrepreneurial leadership) that affect firm performance, particularly within the context of micro-enterprises?" and (2) "how do these attributes contribute to the aspects of performance and sustainability amongst the micro-enterprises?" With rising entrepreneurial social values and ventures, it is prudent to seek features that mold successful entrepreneurs [10]. Specifically within the context of the entrepreneurial leadership characteristic, for instance, Lubis [13] views the concept as relatively new and a growing area of interest that requires deeper knowledge penetration. Meanwhile, micro-enterprises have been reckoned for battling several limitations in terms of personal traits and competencies among owners that hinder their growth, survival, and sustainability [3]. According to Rahman [4], extremely low principal skills are generally one of the main reasons for micro and small businesses to face barriers at accessing formal markets. From the Malaysian perspective, Wahid, Aziz, and Halim [16] highlighted that an inadequate human factor appears to be a major challenge that Malaysian micro-enterprises have to overcome to retain sustenance and competition in the market. Interestingly, most of the existing literature within a similar context to the present study has applied the Resource-Based perspective, but limited to firm performance alone, which seems to defeat the ultimate purpose of the theory in facilitating firms to attain sustainable competitive advantage (sustainability), which refers to superior economic, social, and environmental performance $[17,18]$. In the effort to address the significant gap discovered in enterprise sustainability literature in the context of the Asia-pacific [1] in terms of both theoretical and practical stances, this study investigated the impact of a significant human factor, which is entrepreneurial leadership (i.e., responsibility, accountability, analytical thinking, and emotional intelligence), on the performance and sustainability of micro-enterprises in Kelantan, Malaysia. As such, this study contributes by extending the body of knowledge through the inclusion of sustainability aspects from the viewpoint of micro-enterprises 
from the lens of RBV theory and simultaneously enriching the extant literature, particularly within the context of the Asia-pacific. This study is indeed significant because small firms have been reckoned to cater to large communal groups [9] aside from remaining extensively significant for low-income and underprivileged communities as a powerful tool in eradicating poverty and in empowering the poor economically. The fact that these small firms have been characterized to heavily rely on the resources of owners' characteristics and skills [19] is the prime focus of this particular study.

\section{Literature Review}

\subsection{Theoretical Foundation}

Theoretically, this study is based on the theory of the Resource-based View (RBV), which prescribes organizational resources as the primary drivers of superior enterprise performance [17,20-22]. RBV proposes that organizational resources are rent and yield only when they remain rare, valuable, non-substitutable, and imperfectly imitable [17]. From the stance of RBV, resources denote an accumulation of available factors of production owned or controlled by firms, while capabilities reflect the capacity of firms to deploy resources by means of organizational processes [21]. Grant [20] asserted that capabilities can be perceived as the capacity of an amalgam of resources required to execute certain activities or tasks, which are developed into functional and sub-functional clusters by integrating human, physical, and technological resources. As leadership abilities appear to be part of valuable resources [18], imposing the RBV perspective within the present context it can be presumed that the identified entrepreneurial-leadership-related capabilities (i.e., responsibility, accountability, analytical thinking, and emotional intelligence), being individual-specific (rare, valuable, non-substitutable, and imperfectly imitable), may have an impact upon enterprise performance and sustainability in a direct manner $[17,20,22]$.

Particularly in the case of micro-enterprises, the theoretical approach of RBV seems relevant primarily because small firms are likely to rely heavily on the resources of owners' characteristics and skills [19]. Hence, the RBV is deemed suitable for this study as the operational environments amidst micro-enterprises are often characterized by uncertain and instable markets, thus demanding high-caliber human resources that are associated with competency to cope. As such, the survival of these small firms is perceived to be highly dependent on human resource endowment and unique and inimitable resources apart from aiding them to be competitive in seizing available opportunities [5]. With that, the RBV has been entrusted with providing the theoretical needs of this study, as it has been deduced that the RBV reinforces the assertion of conceiving micro-enterprises as entities that can survive amidst harsh socio-economic environments through unique leadership dimensions (i.e., responsibility, accountability, analytical thinking, and emotional intelligence) of their managers, which carry synergy benefits that may lead to superior enterprise performance and sustainability of the firm. Therefore, in order to exploit the full potential of the RBV and extend the theory, it is further conceptualized from its viewpoint that acquiring, deploying, and leveraging the identified dimensions of entrepreneurial leadership, as firm-specific internal competencies, may exert a positive effect upon enterprise performance and sustainability among the micro-enterprises in Kelantan, Malaysia $[17,20,22]$.

\subsection{Entrepreneurial Leadership}

Entrepreneurial leadership is parked at the intersection of leadership and entrepreneurship [12] wherein leadership translates the process of influencing [23] whereas entrepreneurship reflects both the entrepreneur and the intersection of an entrepreneur with his or her surrounding opportunities [12]. In reviewing the relevant literature with the objective of identifying the most significant dimensions that reflect entrepreneurial leadership, a list of essential attributes, including vision, opportunity-focused, influencing, planning, motivating, creativity, achievement-oriented, flexibility, persistence, patience, risk-taking, high ambiguity tolerance, tenacity, power-oriented, self-confidence, proactive behaviour, 
and internal locus of control [24,25], has been unraveled where the concepts of entrepreneurship and leadership converge.

In particular, Becherer et al. [24] and Stogdill [25] asserted that one of the significant traits of being a successful leader refers to the desire to accept responsibility as well as to occupy a position of dominance and control. In addition, Natuna and Rinaldi [26] noted that individuals are expected to possess professional accountability as part of their entrepreneurial competence and, especially, to comprehend essential entrepreneurial values, such as creativity, risk-taking, and leadership to name a few. From the stance of the related context, Greenberg et al. [27] upheld that when an organization's future goals and environment reflect the past, it is time for entrepreneurial leaders to adopt analytical models in predicting and managing the situation. Finally, Renko et al. [12] claimed that individual-level antecedents, for example, leader demographics and emotional intelligence, could be highly significant in developing effective entrepreneurial leadership.

As entrepreneurship among low-income or underprivileged entrepreneurs is the locus of this study, it, thus, focuses and builds on the traits or personalities that should be displayed by entrepreneurial leaders [25], instead of their actions [12], as entrepreneurship is exemplified by the traits exhibited by an entrepreneur [28], particularly among entrepreneurial organizations where entrepreneurs play the founding and dominant role for business progression [29]. Hence, based on the above, the selection of the following entrepreneurial leadership components has been conceptualized on empirical evidence that suggests one's personality plays a key role towards the origins of entrepreneurship [30]. With focus placed on the perspectives laid down above, this study limits its discussions to the constructs of immediate interest, i.e., responsibility, accountability, analytical thinking, and emotional intelligence, thus depicting the notion of entrepreneurial leadership and articulating their respective effect on enterprise performance and sustainability.

\subsection{Responsibility and Micro-Enterprise Performance}

Responsibility is reflective of habits that reinforce the capacity of a leader to organize and thereby expedite cooperative efforts generated by alertness and intelligence towards the motives and needs of others and followed by insight into situations [25]. Meanwhile, the performance of a micro-enterprise as a multidimensional construct that blankets the operational and financial outcomes of a firm [31] depicts the personality of the owners [32,33]. Moreover, the RBV upholds that specific traits of business managers from the stance of valuable knowledge, skills, beliefs, and capabilities can accelerate the performance of an organization $[17,20,22]$. Thus, the concept of responsibility viewed as an individual-specific ability may serve as a valuable and unique capability in channeling firms towards superior performance.

Responsibility is closely associated with leadership, and hence, has been reckoned to be an essential characteristic of a leader [25]. Within the context of entrepreneurship, the significance of responsibility as part of a leader's traits can be explained by the fact that entrepreneurs work within a relatively unstructured environment where they need to be wholly responsible for every aspect of the enterprise, such as sales, recruitment, public relations, and negotiations [34,35]. Empirically, Rodríguez and Cruz [36] revealed a positively strong correlation between responsibility (environmental and social) and enterprise performance. In addition, Benavides-Velasco et al. [37] discovered that the adoption of socially responsible approaches did improve firm performance. Besides, from the viewpoint of SMEs, Omerzel and Antoncic [38] asserted that abilities related to entrepreneurial leadership, such as leading a team whilst shouldering responsibilities for a task, is considered to be one of the most crucial factors to boost the growth of SMEs. Therefore, upon considering both the theory and existing literature, the following hypothesis is proposed:

Hypothesis 1 (H1). Responsibility has a significantly positive impact on firm performance among micro-enterprises in Kelantan, Malaysia. 


\subsection{Responsibility and Micro-Enterprise Sustainability}

Enterprise sustainability denotes the stakeholder-focused organizational business protocols that address the integrated economic, environmental, and social aspects of performance over short- and long-term periods within the limits imposed by nature and society [39]. Theory wise, the RBV can be deployed to illustrate the contingency of responsibility, as individual-specific capabilities, so as to instigate superior performance in organizations, thus directing towards sustainability from unique and inimitable resources and capabilities [17,20,22]. Furthermore, the adoption of responsibility-related approaches is known to enhance the capability of firms to create value for their stakeholders, which reflects the centre-stone of the sustainability paradigm [38]. Moreover, responsible initiatives, such as preventing harm towards the environment, do not only minimize operating costs, but also enhance enterprise social reputation [40]. In regard to this, Amran et al. [1] asserted that responsible behavior in an enterprise functions as a sound platform to enhance sustainability. Therefore, socially and environmentally responsible economic activities can be reckoned to be sources of competitive advantage (i.e., superior economic, social, and environmental firm performance). Based on the above discussion, the following hypothesis is proposed.

Hypothesis 2 (H2). Responsibility has a significantly positive impact on sustainability among micro-enterprises in Kelantan, Malaysia.

\subsection{Accountability and Micro-Enterprise Performance}

Accountability in leaders has been considered to be an informal and socio-political process where one is expected to behave in a particular manner to uphold an appropriate social order [41]. Based on the RBV theory, accountability can be characterized as an individual-specific capability that serves as a valuable and unique capability that may lead firms towards superior performance $[17,20,22]$. As leadership is the process of occupying one or more positions of responsibility in group activities [25], it is fundamental that accountability (a socio-psychological process), as a trait displayed by leaders, brings individuals to be held responsible for their actions, and thereby abuse of their otherwise well-connected status can be controlled [41].

As a fundamental construct of organizational theory, accountability has a vital function in managing organizations, particularly within the context of entrepreneurial leadership, where certain organizational members have influence upon others towards achieving organizational goals [41]. Similarly, Tan and Kao [42] noted that accountability has an impact upon work performance. Empirically, Nuhu and Hussani [43] discovered that the accountability and composition exhibited by directors have a positive impact upon perceived enterprise performance. Moreover, based on prior studies, accountability can be regarded as a crucial determinant in promoting performance in firms $[44,45]$. Hence, considering both the theory and existing literature, the following hypothesis is proposed.

Hypothesis 3 (H3). Accountability has a significantly positive impact on firm performance among micro-enterprises in Kelantan, Malaysia.

\subsection{Accountability and Micro-Enterprise Sustainability}

At the core of the sustainability dilemma is the idea that enterprises ought to be made accountable for their actions; not just to their owners, but also to a group of wider stakeholders [46]. Theoretically, the RBV can be deployed to conceptualize accountability, as an individual-specific capability, so as to instigate superior performance in organizations, thus channelling them towards sustainability from unique and inimitable resources [17,20,22]. Gray et al. [47] mentioned that accountability holds substantial potential for both society and ecology. Furthermore, Adams and McNicholas [48] considered the potential of greater accountability in facilitating change for enhanced sustainability 
performance. Within this particular context, Jamali [46] stressed that pressure for accountability, along with the significant expense of producing the desired data, has the ability to generate powerful pressures towards the integration of the financial, social, and environmental performance of an organization. Furthermore, Kobuthi et al. [44] established a link between the accountability and non-financial performance of firms, thus reflecting the social and environmental spheres of corporate sustainability. Meanwhile, Rimvydas [45] claimed that accountability is a key feature of sustainable organizations, highlighting its facilitating role of positioning firms in both local and global markets. Moreover, Perego and Kolk [49] signified the need of accountability for sustainability from the stance of multinational corporations. Thus, considering the above discussion, the following hypothesis is proposed.

Hypothesis 4 (H4). Accountability has a significantly positive impact on sustainability among micro-enterprises in Kelantan, Malaysia.

\subsection{Analytical Thinking and Micro-Enterprise Performance}

Analytical and critical thinking have been perceived as intellectual leadership thinking introversion, whereby an alertness to the surrounding environment and understanding situations are closely associated with leadership capability [25]. Theoretically, the RBV posits that an entrepreneur's analytical thinking as a rare and valuable capability for a firm, inimitable in nature, can generate superior enterprise performance [17]. Empirically, such a capability does not only facilitate leadership experience but also supports leadership training [50]. Besides, analytical thinking represents the ability within one to see beyond simple facts and to think complexly at a more comprehensive level, thus highlighting the significance of the concept among entrepreneurial leaders, who need to address complex issues continuously with relatively intricate solutions, along with an ethical, reflective, or moral approach enhanced by critical thinking [51].

Elson et al. [52] claimed that attention is given by employers and leaders towards the need for critical thinking skills in the workforce arena so as to generate business trends of evidence-based decision-making, thus emphasizing the increasing importance of a critical thinking skill set as well as its impact on professional performance. Within the context of entrepreneurship, business leaders lacking leadership attributes, such as higher cognitive processing, appear to be less effective, hence indicating that a deficiency in critical thinking can negatively affect their ability to lead an enterprise [53]. Meanwhile, Ibdah [54] claimed that analytical thinking, as a means of confronting problems and dealing with both internal and external changes related to varied business activities, boosts the performance level of firms. Additionally, Kealey, Holland, and Watson [55] empirically proved that analytical thinking skills contribute significantly towards performance among students. Hence, considering both the theory and existing literature, the following hypothesis is proposed.

Hypothesis 5 (H5). Analytical thinking has a significantly positive impact on firm performance among micro-enterprises in Kelantan, Malaysia.

\subsection{Analytical Thinking and Micro-Enterprise Sustainability}

Due to the unknown end point of sustainability, as well as the undescribed processes of reaching decision points regarding sustainability, those with the ability to think and to assess the usefulness of such processes and options may offer a sustainable future [56]. In particular, analytical-operational models can articulate a market principle by generating and evaluating social values, hence facilitating the management of social, economic, and environmental functions in association with entrepreneurship [57]. Leaning on the RBV theory, the trait of analytical thinking has been propounded as a unique and inimitable resource that instigates superior enterprise performance, thus promoting sustenance among firms [17,20,22]. According to Thomas [56], a range of analytical- 
and context-related skills need to be developed to achieve both sustainability and sustainable development. Prior studies have stressed that developing dynamic business strategies required for sustainability is contingent on sensible and responsive thinking [58,59]. In a related context, Liu [60] noted that the sustainable competitiveness of organizational operations within a dynamic and complex business environment depends on viable thinking strategies. Burnard and Bhamra [32] claimed that analytical thinking supports characterizing the responses of an organization towards disruptive events aside from facilitating organizational sustainable development by outlining the essential processes that are deemed necessary to elicit a resilient response. Additionally, Menzel [61] highlighted that both emotions and analytical information processing influence decision-making and implications for fostering sustainability. Therefore, based on the discussion above, the following is hypothesized.

Hypothesis 6 (H6). Analytical thinking has a significantly positive impact on sustainability among micro-enterprises in Kelantan, Malaysia.

\subsection{Emotional Intelligence and Micro-Enterprise Performance}

Emotional intelligence reflects the abilities of individuals in addressing not only their own emotions but also those of others to assist in decision-making and problem-solving [62]. Kuratko [35] asserted that motivational and self-influence constructs, such as emotional intelligence, are closely relevant to the concept of self-leadership. Emotional intelligence within the present context is defined as a set of cognitive capabilities and self-efficacy that enable individuals to monitor their own feelings and emotions, apart from understanding how such feelings or emotions can be distinguished from those of others, and thereby, the output information can be used to guide their emotions and thinking as they explore business ventures [63-66]. According to Nanayakkara, Wickramasinghe, and Samarasinghe [67], leaders with a higher level of emotional intelligence are more likely to reap higher profits.

A study has found that indicators of emotional intelligence, such as ability (cognitive ability tests), are vital in predicting maximum performance, whereas the non-ability dimension of emotional intelligence measures personality tests, for instance, to correlate it with typical performance [68]. Empirical evidence further suggests that emotional intelligence offers complete coverage of emotion-centred self-perceptions that may influence firm-level variables, such as job satisfaction and firm performance, in a direct manner [68]. Meanwhile, Heffernan et al. [69] revealed a significant correlation between emotional intelligence and financial performance by implicating that higher levels of emotional intelligence displayed by the managers can be translated into higher profitability. Particularly within the context of SMEs, Aslam et al. [70] discovered a positive relationship between the emotional intelligence of entrepreneurs and firm performance. Hence, the following hypothesis is proposed based on theory and the existing literature.

Hypothesis 7 (H7). Emotional intelligence has a significantly positive impact on firm performance among micro-enterprises in Kelantan, Malaysia.

\subsection{Emotional Intelligence and Micro-Enterprise Sustainability}

Effective leadership that results within the time frames required for industries and stakeholders is generated through a much needed critical element: emotional intelligence [70]. In accordance with the RBV theory, an entrepreneur's emotional intelligence, as an individual-specific capability, may lead to superior performance in organizations, thus channelling them towards sustainability from unique and inimitable resources [71,72]. Empirically, Nanayakkara et al. [67] found that emotional intelligence displayed a significant effect on non-financial organizational performance, which is a social and an environmental sphere of sustainability. Social and emotional competencies, such as 
the ability to manage ones' own emotions, effectively solving problems, and cooperatively working with others, are integral elements to attain work-related sustainability. Humphrey et al. [73] further provided support to the view that both social and emotional aspects of learning have to be considered for long-term organizational impact and sustainability. Hence, the above discussion dictates the following hypothesis.

Hypothesis 8 (H8). Emotional intelligence has a significantly positive impact on sustainability among micro-enterprises in Kelantan, Malaysia.

\subsection{Micro-Enterprise Performance and Sustainability}

In this study, the aspect of enterprise performance is conceptualized as a multidimensional construct that blankets the operational and financial outcomes of a firm [31]. Meanwhile, enterprise sustainability refers to stakeholder-focused organizational systems that address the integrated economic, environmental, and social aspects of performance over short- and long-term periods within the limits imposed by nature and society [39]. On this, a recent review is has found a positive correlation between firm performance and enterprise sustainability performance [62]. In addition, Mishra and Suar [74] purported to establish a positive link between firm performance and corporate sustainability. Nevertheless, López, Garcia, and Rodriguez [75] reported a negative correlation between the two constructs, whereas Jacobs, Singhal, and Subramanian [76] revealed an insignificant association between firm performance and sustainability. The inconclusive contradictory results of prior studies indicate that deeper research penetration on the subject matter is required. Hence, based on the aforesaid, the following hypothesis is proposed.

Hypothesis 9 (H9). Enterprise performance has a significantly positive impact on sustainability among micro-enterprises in Kelantan, Malaysia.

\subsection{The Mediating Effect of Micro-Enterprise Performance}

This study conceptualizes responsibility, accountability, analytical thinking, and emotional intelligence as influential factors towards micro-enterprise performance and concurrently propounds that enterprise performance is an enabler of micro-enterprise sustainability. Entrepreneurial leadership, without doubt, has a significant role in determining superior business performance [13] particularly among small-scale businesses. Hence, entrepreneurial leadership has remained essential as micro-entrepreneurs may not successfully develop their businesses without displaying effective leadership traits [14]. Theoretically, from the stance of RBV, one can perceive responsibility, accountability, analytical thinking, and emotional intelligence as rare, valuable, and inimitable resources that promote additional capabilities (i.e., improved firm performance) amidst firms, thus directing them towards a sustainable competitive advantage (i.e., sustainability) $[17,20]$. Moreover, most cited literature appears to indicate a significantly positive effect of the identified dimensions found in entrepreneurial leadership (i.e., responsibility, accountability, analytical thinking, and emotional intelligence) on an enterprise's performance cf. [34-36,38,43,44,53-55,67,68]. At the same time, the existing literature suggests a significantly positive relationship between enterprise performance and sustainability $[74,75]$. With that, this study assumes that the adoption of entrepreneurial-leadership-related dimensions could improve the capacity among micro-enterprises to perform better, thus generating sustainable benefits for their stakeholders, while simultaneously implicating that enterprise performance has a significant mediating effect on the correlations of responsibility, accountability, analytical thinking, and emotional intelligence with micro-enterprise sustainability. Hence, it is indeed necessary to enhance our comprehension regarding the interplay between the variables so as to reveal latent and casual relationships between the constructs of interest as well as to offer the robust outcomes that this study has hypothesized, as given in the following, in 
order to examine the indirect effect (apart from the direct effect) of entrepreneurial leadership components on enterprise sustainability:

Hypothesis $\mathbf{M 1}\left(\mathrm{H}_{\mathbf{M 1}}\right)$. Micro-Enterprise Performance significantly mediates the relationship between Responsibility and sustainability among micro-enterprises in Kelantan, Malaysia.

Hypothesis $\mathbf{M} 2\left(\mathbf{H}_{\mathbf{M} 2}\right)$. Micro-Enterprise Performance significantly mediates the relationship between Accountability and sustainability among micro-enterprises in Kelantan, Malaysia.

Hypothesis $\mathbf{M} 3\left(\mathrm{H}_{\mathrm{M} 3}\right)$. Micro-Enterprise Performance significantly mediates the relationship between Analytical thinking and sustainability among micro-enterprises in Kelantan, Malaysia.

Hypothesis M4 $\left(\mathrm{H}_{\mathbf{M} 4}\right)$. Micro-Enterprise Performance significantly mediates the relationship between Emotional intelligence and sustainability among micro-enterprises in Kelantan, Malaysia.

\section{Research Methodology}

This study employed a cross-sectional research design and gathered quantitative data from structured interview sessions held in an attempt to measure the impacts of responsibility, accountability, analytical thinking, and emotional intelligence on the performance and sustainability of micro-enterprises in Kelantan, Malaysia. The study population is comprised of micro-entrepreneurs from low-income households in Kelantan, Malaysia. The list of registered low-income households in Kelantan was retrieved from two government agencies that place emphasis on fostering socio-economic progression among low-income households. As such, "Majlis Amanah Rakyat" Kelantan and "Majlis Agama Islam Dan Adat Istiadat" Kelantan provided lists of 2690 and 105 micro-entrepreneurs from low-income households in Kelantan, Malaysia. From the complete list of 2795 low-income micro-entrepreneurs, 425 micro-entrepreneurs had been randomly selected from nine districts in Kelantan, namely Tumpat, Bachok, Jeli, Machang, Gua Musang, Kuala Krai, Pasir Puteh, Pasir Mas, and Tanah Merah. Prior to data collection, the data collection team contacted the selected respondents to explain the objectives of the survey and to set an appointment for the interview sessions. The complete data were gathered between September and November 2017, whereby 403 respondents allowed the researchers to visit their premises and hold interview sessions.

\subsection{Sample Size}

The study sample size was determined via G-Power version 3.1. Based on the power of 0.95 (greater than 0.80 , as required in social and behavioral science research) with an effect size of 0.15 , this study required a sample size of 138 to test a model with five predictors. Besides this, Reinartz, Haenlein, and Henseler [77] proposed a minimum threshold of 100 samples for structural equation modelling via partial least squares (PLS-SEM). Furthermore, in order to avoid any possible complication that may arise due to a small sample size, this study collected data from 403 micro-entrepreneurs residing in nine districts spread around Kelantan, Malaysia.

\subsection{Research Instrument}

The questionnaire was designed by incorporating simple and non-intricate terms to ease comprehension of the questions and for the respondents to provide answers based on their own viewpoints. The survey items were adapted from prior studies with minor alterations in several required sections (complete questionnaire in Appendix A). The items employed to measure Responsibility were adopted from Berkowitz and Daniels [78]. As for Accountability, the questions were adopted from Thoms, Dose, and Scott [79], while items that measured Analytical thinking were adopted from Epstein, Pacini, Denes-Raj, and Heier [80]. Next, items for Emotional intelligence were retrieved from Schutte et al. [81], whereas questions pertaining to Micro-Enterprise performance were 
adopted from Morgan and Strong [82], and questions regarding Micro-Enterprise sustainability were adopted from Raymond et al. [83] and Gualandris et al. [84]. In addition, a seven-point Likert scale ( 1 to 7 , from "strongly disagree" to "strongly agree") was used for micro-enterprise performance and sustainability, while a five-point Likert scale (1 to 5 , from 'strongly disagree' to 'strongly agree') was applied for all of the independent variables.

\subsection{Common Method Variance (CMV)}

As a procedural remedy to minimize the effect of common method bias, apart from carefully constructing the items, this study also "informed the respondent that the responses are evaluated anonymously and there is no right or wrong answer" at the point of data collection [85]. Besides, as recommended by Podsakoff et al. [85], the five-point Likert scale was applied for all independent variables, while the seven-point Likert scale was used for dependent variables. For a statistical remedy, the Harman's [86] one-factor test was adopted, as suggested by Podsakoff et al. [85], whereby one fixed factor extracted from all principal constructs is expected to explain less than $50 \%$ of the variance. The outcomes showed that one component explained $25.60 \%$ of the variance, which is less than the maximum threshold of $50 \%$. In addition, correlations between the constructs that exceed 0.9 have been considered as indicators of common method bias [87]. The highest correlation between the constructs was 0.544 (between responsibility and accountability), which indicates a lack of common method bias in the collected data.

\subsection{Multivariate Normality}

This study tested the multivariate normality by using the Web Power online tool. The Web Power tool that calculated Mardia's multivariate skewness and kurtosis coefficients, as well as $p$-values, displayed results below 0.05 , hence confirming multivariate non-normality.

\subsection{Data Analysis Method}

Structural equation modelling via partial least squares (PLS-SEM) refers to a causal modelling approach that maximizes the explained variance of the dependent latent constructs [88]. Moreover, due to the exploratory nature of this study and the non-normality issue, this study employed a PLS-SEM estimation with the primary objective of maximizing the explanation of variance among the dependent constructs embedded in the structural equation model. The results of this analysis are reported as recommended by Hair, Ringle, and Sarstedt [89] for PLS modelling, which are inclusive of indicator reliability, internal consistency reliability, convergent validity, discriminant validity, Average Variance Extracted (AVE), effect size, path coefficient estimates, and predictive relevance.

\section{Summary of Findings}

\subsection{Demographic Characteristics}

Data were collected from 403 micro-entrepreneurs (51.6\% males and 48.4\% females) in Kelantan, Malaysia for this study (see Table 1). Most respondents belonged to the 20 to 30 (29.5\%) and 31 to 40 $(29.3 \%)$ age groups. As for education qualification, $58.1 \%$ of the respondents claimed to have completed secondary school, and $79.9 \%$ of the respondents are married. Out of the 403 respondents, $286(71 \%)$ had no prior business experience, while the other 117 (29\%) admitted possessing prior business experience. Out of the 117 respondents with experience, 54 (a majority) reported to have only one year of prior business experience, which was followed by 24 respondents with two years of experience, 15 with four years of experience, 14 with more than five years of experience, and 10 respondents with three years of prior business experience. Finally, as for the duration that a firm has been established, 136 (majority) respondents have been operating their firms for between 6 and 10 years, which was closely followed by 129 respondents with firms running from 1 to 5 years, while only $16(4 \%)$ respondents have firms that are less than a year old. 
Table 1. Profile of the Respondents.

\begin{tabular}{|c|c|c|c|c|c|}
\hline & $\mathbf{n}$ & $\%$ & & $\mathbf{N}$ & $\%$ \\
\hline \multicolumn{3}{|c|}{ Gender } & \multicolumn{3}{|c|}{ Education } \\
\hline Male & 208 & 51.6 & Never attended school & 5 & 1.2 \\
\hline Female & 195 & 48.4 & Primary School & 22 & 5.5 \\
\hline Total & 403 & 100.0 & Secondary School & 234 & 58.1 \\
\hline \multicolumn{3}{|c|}{ Age } & STPM/Diploma & 80 & 19.9 \\
\hline 20-30 years old & 68 & 16.9 & Undergraduate Degree & 41 & 10.2 \\
\hline $31-40$ years old & 119 & 29.5 & Masters Degree & 3 & 0.7 \\
\hline $41-50$ years old & 118 & 29.3 & Others & 18 & 4.5 \\
\hline $51-60$ years old & 78 & 19.4 & Total & 403 & 100.0 \\
\hline 61 years old and above & 20 & 4.9 & \multicolumn{3}{|c|}{ Previous Business Experience } \\
\hline Total & 403 & 100.0 & Yes & 117 & 29.0 \\
\hline \multicolumn{3}{|c|}{ Marital Status } & No & 286 & 71.0 \\
\hline Single & 53 & 13.2 & Total & 403 & 100.0 \\
\hline Married & 322 & 79.9 & \multicolumn{3}{|c|}{ Firm Established } \\
\hline Divorced & 13 & 3.2 & Less 1 year & 16 & 4.0 \\
\hline Widowed & 15 & 3.7 & $1-5$ Years & 129 & 32.0 \\
\hline \multirow[t]{5}{*}{ Total } & 403 & 100.0 & 6-10 years & 136 & 33.7 \\
\hline & & & $11-15$ years & 57 & 14.1 \\
\hline & & & 16-20 years & 34 & 8.4 \\
\hline & & & More than 20 years & 31 & 7.7 \\
\hline & & & Total & 403 & 100.0 \\
\hline
\end{tabular}

Note: STPM—Sijil Tinggi Persekolahan Malaysia. Source: Author(s) own compilation.

\subsection{Reliability and Validity}

Table 2 presents the descriptive statistics along with the criteria used to evaluate the reliability of the items employed in this study. The values of mean and standard deviation for all the variables (i.e., Responsibility, Accountability, Analytical thinking, Emotional intelligence, Micro-Enterprise performance, and Micro-Enterprise sustainability) are tabulated in Table 2. In fact, the mean value for analytical thinking, as presented in Table 2, seems to be relatively low with a slightly higher standard deviation, indicating that not all micro-entrepreneurs possessed similar levels of analytical thinking. This applies as the reason for the micro-enterprises to have achieved varied levels of performance and sustainability based on the relatively higher standard deviation values for micro-enterprise performance and sustainability.

Table 2. Reliability and Validity.

\begin{tabular}{lcccccccc}
\hline \multicolumn{1}{c}{ Variables } & Items & Mean & SD & CA & DG rho & CR & AVE & VIF \\
\hline Responsibility & 4 & 4.263 & 0.439 & 0.692 & 0.701 & 0.809 & 0.515 & 1.498 \\
Accountability & 4 & 4.187 & 0.483 & 0.703 & 0.708 & 0.817 & 0.528 & 1.628 \\
Analytical thinking & 7 & 3.859 & 0.622 & 0.848 & 0.862 & 0.883 & 0.522 & 1.367 \\
Emotional intelligence & 5 & 4.005 & 0.610 & 0.790 & 0.805 & 0.853 & 0.538 & 1.389 \\
Micro-Enterprise performance & 5 & 5.857 & 0.739 & 0.868 & 0.878 & 0.904 & 0.653 & 1.207 \\
Micro-Enterprise sustainability & 5 & 5.570 & 0.804 & 0.764 & 0.779 & 0.840 & 0.514 & - \\
\hline
\end{tabular}

Note: Standard Deviation (SD); Cronbach's Alpha (CA); Dillon-Goldstein's rho (DG rho); Composite Reliability (CR); Average Variance Extracted (AVE); Variance Inflation Factors (VIF). Source: Author(s) own compilation.

The Cronbach's alpha is a conservative measure of internal consistency reliability. The Cronbach's alpha reliability analysis revealed that all variables, except Responsibility, have values that exceed 0.7, indicating that all the items are indeed reliable. The Cronbach's alpha value for Responsibility, 
nevertheless, is 0.692 , which is close to 0.7; thus, it is considered reliable. According to Hair et al. [80], it is also appropriate to apply varied measures of internal consistency reliability, known as "composite reliability", with a cut-off value of 0.7 [79]. As displayed in Table 2, the composite reliability values for all variables exceed 0.8, which signifies reliability. Moreover, the Dillon-Goldstein rho values for all indicators are greater than 0.7 , thus confirming the reliability of the items. Next, in order to achieve convergent validity, the AVE value should be higher than 0.50. As shown in Table 2, the AVE values for all constructs are indeed higher than 0.50 , thus ratifying acceptable convergent validity. Finally, this study tested the variance inflation factors (VIF) to detect a multicollinearity issue. As a result, the VIF values for all variables are below 3.3, which dismisses multicollinearity as a serious issue for the study dataset [90].

As for reliability, the loading and cross-loading values projected in Table 3 display that all the indicator loadings exceed 0.6. Therefore, based on Chin's [91] suggestion that indicators with a loading higher than 0.5 can be retained, all items embedded in this study have been considered as reliable. Moreover, the values of cross-loading depicted in Table 3 are higher than the total cross-loadings, hence affirming discriminant validity. Furthermore, for discriminant validity, based on the Fornell-Larcker criterion, the AVE for each indicator should exceed the construct's highest squared correlation with another construct. As noted in Table 3, all the constructs have managed to meet this criterion. Finally, the Heterotrait-Monotrait Ratio (HTMT) is an estimate of the correlation between constructs, paralleling the disattenuated construct score. With 0.9 as the threshold, this study dismisses a lack of discriminant validity within the dataset of this study.

Table 3. Loadings and Cross-Loadings.

\begin{tabular}{lcccccc}
\hline & RS & AC & AT & EI & EP & ES \\
\hline RS: Item 1 & 0.731 & 0.379 & 0.185 & 0.159 & 0.262 & 0.210 \\
RS: Item 2 & 0.742 & 0.459 & 0.254 & 0.320 & 0.248 & 0.318 \\
RS: Item 3 & 0.732 & 0.401 & 0.211 & 0.141 & 0.161 & 0.231 \\
RS: Item 4 & 0.663 & 0.334 & 0.110 & 0.163 & 0.226 & 0.139 \\
AC: Item 1 & 0.387 & 0.779 & 0.377 & 0.286 & 0.250 & 0.385 \\
AC: Item 2 & 0.449 & 0.729 & 0.222 & 0.204 & 0.352 & 0.343 \\
AC: Item 3 & 0.405 & 0.688 & 0.207 & 0.255 & 0.233 & 0.311 \\
AC: Item 4 & 0.368 & 0.708 & 0.232 & 0.279 & 0.159 & 0.370 \\
AT: Item 1 & 0.224 & 0.264 & 0.785 & 0.346 & 0.106 & 0.296 \\
AT: Item 2 & -0.008 & 0.170 & 0.681 & 0.289 & -0.055 & 0.247 \\
AT: Item 3 & 0.176 & 0.241 & 0.712 & 0.366 & 0.125 & 0.305 \\
AT: Item 4 & 0.222 & 0.332 & 0.762 & 0.368 & 0.099 & 0.273 \\
AT: Item 5 & 0.182 & 0.294 & 0.814 & 0.378 & 0.191 & 0.377 \\
AT: Item 6 & 0.119 & 0.207 & 0.612 & 0.318 & 0.160 & 0.246 \\
AT: Item 7 & 0.333 & 0.264 & 0.669 & 0.301 & 0.374 & 0.311 \\
EI: Item 1 & 0.225 & 0.294 & 0.335 & 0.737 & 0.185 & 0.294 \\
EI: Item 2 & 0.263 & 0.230 & 0.300 & 0.736 & 0.214 & 0.122 \\
EI: Item 3 & 0.166 & 0.157 & 0.338 & 0.668 & 0.200 & 0.167 \\
EI: Item 4 & 0.112 & 0.232 & 0.351 & 0.765 & 0.174 & 0.274 \\
EI: Item 5 & 0.275 & 0.324 & 0.385 & 0.759 & 0.272 & 0.321 \\
EP: Item 1 & 0.295 & 0.309 & 0.133 & 0.238 & 0.816 & 0.425 \\
EP: Item 2 & 0.262 & 0.343 & 0.252 & 0.306 & 0.806 & 0.454 \\
EP: Item 3 & 0.175 & 0.229 & 0.073 & 0.157 & 0.778 & 0.307 \\
EP: Item 4 & 0.205 & 0.209 & 0.215 & 0.200 & 0.806 & 0.423 \\
EP: Item 5 & 0.311 & 0.293 & 0.240 & 0.236 & 0.835 & 0.478 \\
ES: Item 1 & 0.100 & 0.291 & 0.274 & 0.237 & 0.204 & 0.623 \\
ES: Item 2 & 0.243 & 0.414 & 0.368 & 0.240 & 0.337 & 0.748 \\
ES: Item 3 & 0.122 & 0.338 & 0.321 & 0.234 & 0.285 & 0.673 \\
\hline
\end{tabular}


Table 3. Cont.

\begin{tabular}{lcccccc}
\hline & RS & AC & AT & EI & EP & ES \\
\hline ES: Item 4 & 0.311 & 0.323 & 0.243 & 0.250 & 0.467 & 0.740 \\
ES: Item 5 & 0.329 & 0.365 & 0.299 & 0.266 & 0.523 & 0.788 \\
\hline Fornell-Larcker Criterion & & & & & & \\
Responsibility (RS) & 0.717 & & & & & \\
Accountability (AC) & 0.555 & 0.727 & & & & \\
Analytical thinking (AT) & 0.274 & 0.359 & 0.722 & & & \\
Emotional intelligence (EI) & 0.287 & 0.350 & 0.471 & 0.734 & & \\
Micro-Enterprise performance (EP) & 0.317 & 0.349 & 0.236 & 0.289 & 0.808 & \\
Micro-Enterprise sustainability (ES) & 0.325 & 0.484 & 0.417 & 0.341 & 0.526 & 0.717 \\
\hline Fornell-Larcker Criterion & & & & & & \\
Responsibility (RS) & - & & & & & \\
Accountability (AC) & 0.779 & - & & & & \\
Analytical thinking (AT) & 0.347 & 0.451 & - & & & \\
Emotional intelligence (EI) & 0.362 & 0.455 & 0.563 & - & & \\
Micro-Enterprise performance (EP) & 0.391 & 0.429 & 0.251 & 0.334 & - & \\
Micro-Enterprise sustainability (ES) & 0.442 & 0.658 & 0.510 & 0.412 & 0.609 & - \\
\hline
\end{tabular}

Note: The Italic values in the matrix above are the item loadings and others are cross-loadings. Source: Author's data analysis.

\subsection{Path Analysis}

The path coefficients, as presented in Figure 1 and Table 4, exemplify that the coefficient value for Responsibility on Micro-Enterprise Performance (Hypothesis 1) is 0.152 with a $p$-value of 0.011 (at $5 \%$ significance), signifying that the level of responsibility among micro-entrepreneurs has a significantly positive effect on their firm performance. Besides this, the $f^{2}$ value of 0.019 points out an insignificant effect of Responsibility on Micro-Enterprise Performance. The coefficient value for Responsibility on Micro-Enterprise Sustainability (Hypothesis 2), surprisingly, appears negative (0.014) with a $p$-value of 0.765 , reflecting that Responsibility is not statistically significant, but has a positive effect on Micro-Enterprise Sustainability. The $f^{2}$ value of 0.000 indicates that Responsibility has zero effect on the Sustainability of Micro-enterprises owned by the respondents.

Meanwhile, the coefficient for Accountability on Micro-Enterprise Performance has a positive value of 0.192 and a $p$-value of 0.012 (Hypothesis 3), indicating that the level of Accountability exerted by the respondents has a significantly positive effect on their firm's performance. Moreover, the $f^{2}$ value of 0.028 indicates a small effect of accountability among the low-income household heads on Micro-Enterprise Performance. On the other hand, the path coefficient value for Accountability on Enterprise Sustainability (Hypothesis 4) is 0.270 with a $p$-value of 0.000 , which signifies that the aspect of Accountability exhibited by the respondents has a significantly positive effect on micro-enterprise sustainability. The $f^{2}$ value of 0.078 reflects a small to medium effect of Accountability on the Sustainability of Micro-enterprises in Kelantan, Malaysia.

Table 4. Path Analysis.

\begin{tabular}{ccccccccc}
\hline Hypothesis & Association & Coefficient & $t$ Value & Sig. & Decision & $r^{2}$ & $f^{2}$ & $Q^{2}$ \\
\hline H1 & RS $\rightarrow$ EP & 0.152 & 2.542 & 0.011 & Accept & & 0.019 & \\
H3 & AC $\rightarrow$ EP & 0.192 & 2.511 & 0.012 & Accept & & 0.028 & \multirow{2}{*}{0.097} \\
H5 & AT $\rightarrow$ EP & 0.053 & 0.857 & 0.392 & Reject & 0.172 & 0.002 & \\
H7 & EI $\rightarrow$ EP & 0.153 & 2.479 & 0.014 & Accept & & 0.021 & \\
H2 & RS $\rightarrow$ ES & -0.014 & 0.299 & 0.765 & Reject & & 0.000 & \\
H4 & AC $\rightarrow$ ES & 0.270 & 3.860 & 0.000 & Accept & & 0.078 & \\
H6 & AT $\rightarrow$ ES & 0.217 & 3.700 & 0.000 & Accept & 0.427 & 0.060 & 0.196 \\
H8 & EI $\rightarrow$ ES & 0.040 & 0.753 & 0.452 & Reject & & 0.002 & \\
H9 & EP $\rightarrow$ ES & 0.373 & 6.897 & 0.000 & Accept & & 0.201 & \\
\hline
\end{tabular}

Notes: Responsibility (RS), Accountability (AC), Analytical thinking (AT), Emotional intelligence (EI), Micro-Enterprise performance (EP), Micro-Enterprise sustainability (ES). Source: Author(s) own compilation. 
Next, the coefficient for Analytical thinking shows a positive $(\beta=0.053)$ but statistically insignificant ( $p$-value $=0.392$ ) effect on Micro-Enterprise Performance (Hypothesis 5). Moreover, the $f^{2}$ value of 0.002 indicates a near-zero effect of analytical thinking on the performance of enterprises run by low-income household heads. The path coefficient value for analytical thinking on Micro-Enterprise sustainability (Hypothesis 6) is 0.217 with a $p$-value of 0.000 , indicating that analytical thinking among low-income household heads has a significantly positive effect on their micro-enterprise's sustainability. Besides this, the $f^{2}$ value of 0.060 points out a small to medium effect size of analytical thinking on the sustainability of micro-enterprises in Kelantan, Malaysia.

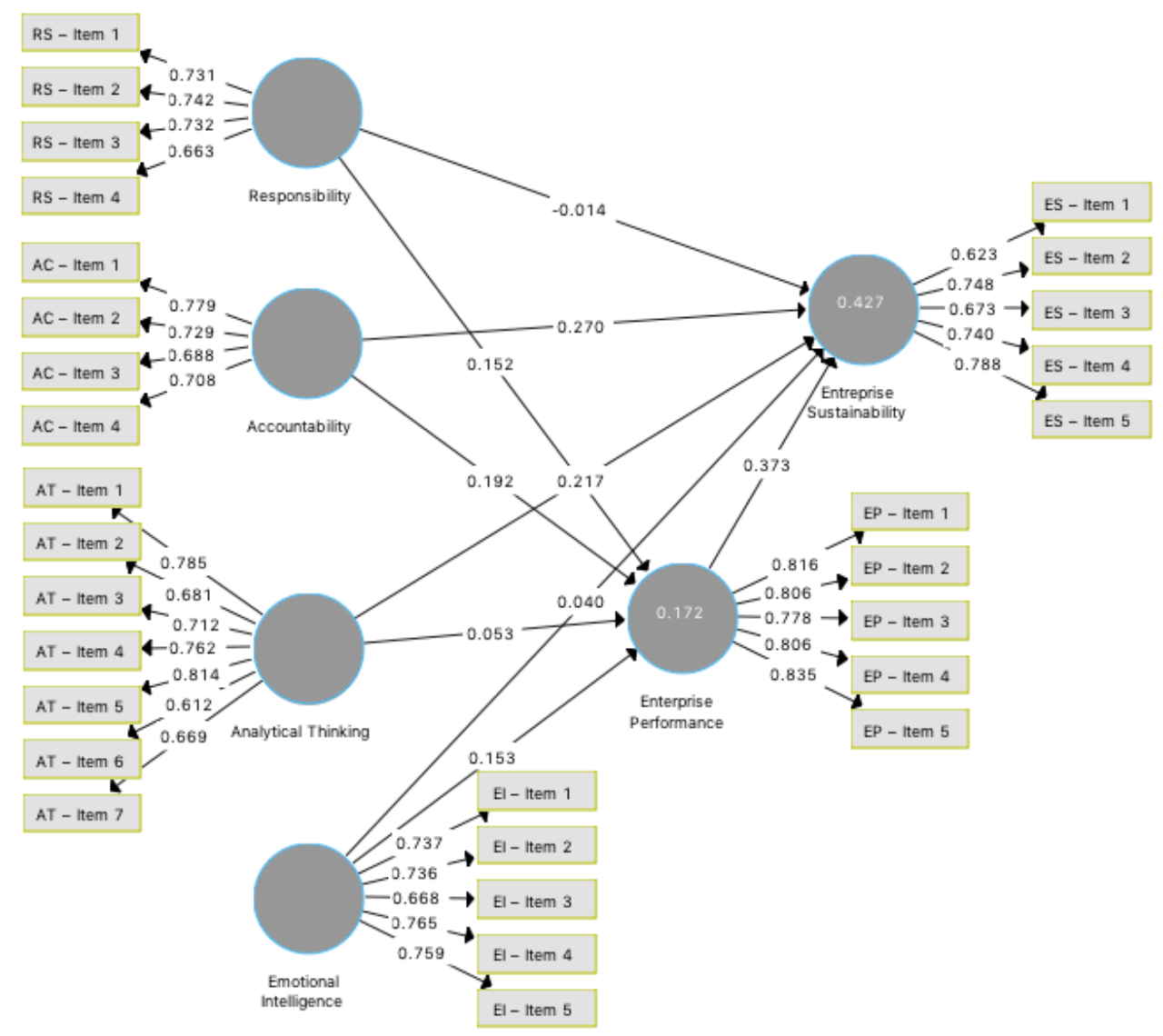

Figure 1. Path Analysis.

The coefficient for Emotional intelligence presents a positive $(\beta=0.153)$ and a significant ( $p$-value of $0.014<0.05$ ) effect on Micro-Enterprise Performance among micro-enterprises in Kelantan, Malaysia (Hypothesis 7). The $f^{2}$ value of 0.21 signifies a small effect of Emotional intelligence on Micro-Enterprise Performance among micro-enterprises in Kelantan. The coefficient for Emotional intelligence displays a positive $(\beta=0.040)$ but statistically insignificant ( $p$-value $=0.452)$ impact on Micro-Enterprise sustainability (Hypothesis 8 ). The $f^{2}$ value of 0.002 reflects a near-zero effect of Emotional Intelligence exerted by low-income household heads on the sustainability of their micro-enterprises. Lastly, the coefficient for Micro-Enterprise Performance shows a positive $(\beta=0.373)$ and significant $(p$-value of $0.000<0.05$ ) effect on Micro-Enterprise sustainability (Hypothesis 9). Besides this, the $f^{2}$ value of 0.201 signifies a moderate to high effect of Micro-Enterprise Performance on the Sustainability of Micro-enterprises owned by low-income household heads in Kelantan, Malaysia.

The value of $r$, which refers to the degree of explained variance, is 0.172 for the performance of micro-enterprises, indicating that $17.2 \%$ of the variation in micro-enterprise performance can be explained by Responsibility, Accountability, Analytical thinking, and Emotional intelligence. As for micro-enterprise sustainability, the $r^{2}$ value is 0.427 , signifying that an essential fraction 
$(42.7 \%)$ of the variation in micro-enterprise sustainability can be explained by Responsibility, Accountability, Analytical thinking, Emotional intelligence, and Micro-enterprise Performance. Furthermore, the $Q^{2}$ value of 0.097 (above 0) points out that the identified factors (i.e., Responsibility, Accountability, Analytical thinking, and Emotional intelligence) have low predictive relevance for micro-enterprise performance. Next, the $Q^{2}$ value of 0.427 for micro-enterprise sustainability signifies that the identified factors (Responsibility, Accountability, Analytical thinking, Emotional intelligence, and Micro-enterprise performance) possess high predictive relevance for the sustainability of micro-enterprises in Kelantan, Malaysia.

\subsection{Mediating Effects}

As for the mediating effects of Micro-Enterprise performance, this study shows indirect effect coefficients, confidence intervals, and $p$-values in Table 5. The table reveals that responsibility has a significantly ( $p$-values $<0.05$ ) positive and indirect effect on micro-enterprise sustainability among the low-income household heads in Kelantan, Malaysia (at 5\% significance), thus confirming the significant mediating effect of micro-enterprise performance on the correlation between responsibility and micro-enterprise sustainability (Hypothesis M1). In addition, Table 5 reveals that accountability does not have a significantly indirect effect on micro-enterprise sustainability, which projects that micro-enterprise performance does not mediate the relationship between accountability and micro-enterprise sustainability (Hypothesis M2) among the respondents. Next, as for analytical thinking, Table 5 displays a significantly $(p$-values $<0.05)$ positive and indirect effect on micro-enterprise sustainability among the low-income household heads in Kelantan, Malaysia, hence affirming the mediating effect of micro-enterprise performance for the correlation between analytical thinking and micro-enterprise sustainability (Hypothesis M3). Lastly, a significantly positive and indirect effect of emotional intelligence is displayed on micro-enterprise sustainability among the respondents, hence ratifying the mediating effect of micro-enterprise performance on the correlation between emotional intelligence and micro-enterprise sustainability (Hypothesis M4).

Table 5. Mediating Effects.

\begin{tabular}{llccccc}
\hline & Path & Beta & CI-Min & CI-Max & Sig. & Decision \\
\hline $\mathrm{H}_{\mathrm{M} 1}$ & $\mathrm{RS} \rightarrow \mathrm{EP} \rightarrow \mathrm{ES}$ & 0.072 & 0.008 & 0.134 & 0.026 & Mediation \\
$\mathrm{H}_{\mathrm{M} 2}$ & $\mathrm{AC} \rightarrow \mathrm{EP} \rightarrow \mathrm{ES}$ & 0.020 & -0.025 & 0.072 & 0.416 & No Mediation \\
$\mathrm{H}_{\mathrm{M} 3}$ & $\mathrm{AT} \rightarrow \mathrm{EP} \rightarrow \mathrm{ES}$ & 0.057 & 0.015 & 0.112 & 0.023 & Mediation \\
$\mathrm{H}_{\mathrm{M} 4}$ & $\mathrm{EI} \rightarrow \mathrm{EP} \rightarrow \mathrm{ES}$ & 0.057 & 0.010 & 0.104 & 0.014 & Mediation \\
\hline
\end{tabular}

Notes: Responsibility (RS), Accountability (AC), Analytical thinking (AT), Emotional intelligence (EI), Micro-Enterprise performance (EP), Micro-Enterprise sustainability (ES). Source: Author(s) own compilation.

\subsection{Multi-Group Analysis}

In the attempt to provide enhanced understanding from both theoretical and practical perspectives, this study probed into the model by employing the multi-group analysis (PLS-MGA) approach. Among the vast antecedents, this study selected gender, marital status, and education subgroups in particular for this analysis. Nevertheless, the scarcity of cases in several subgroups led to a singular matrix error. As such, this study selected the top two groups with the highest number of respondents based on marital status and education. The outcomes signified a significant difference in the effect of analytical thinking upon micro-enterprise sustainability among male and female micro-entrepreneurs. As for marital status, the effects of analytical thinking on microenterprise performance and responsibility on microenterprise sustainability are significantly higher for single respondents than that of married respondents. Lastly, the outcomes displayed no significant variance for the effect of responsibility, accountability, analytical thinking, and emotional intelligence on micro-enterprise performance and sustainability amidst micro-entrepreneurs with varied levels of education (Secondary School, STPM, or Diploma). Moreover, the $p$-values of all other associations ( 25 out of 27 associations presented in Table 6) appear to exceed 0.05 , thus indicating a lack of the heterogeneity issue. 
Table 6. Multi-group Analysis.

\begin{tabular}{|c|c|c|c|c|}
\hline Gender & $\begin{array}{c}\text { Male } \\
(\text { Beta })\end{array}$ & $\begin{array}{l}\text { Female } \\
(\text { Beta })\end{array}$ & $\begin{array}{l}\text { Male-Female } \\
\quad(\text { Beta })\end{array}$ & $\begin{array}{l}\text { Male-Female } \\
(p \text { Value })\end{array}$ \\
\hline $\mathrm{RS} \rightarrow \mathrm{EP}$ & 0.224 & 0.112 & 0.111 & 0.176 \\
\hline $\mathrm{AC} \rightarrow \mathrm{EP}$ & 0.116 & 0.259 & 0.143 & 0.832 \\
\hline $\mathrm{AT} \rightarrow \mathrm{EP}$ & 0.031 & 0.091 & 0.059 & 0.678 \\
\hline $\mathrm{EI} \rightarrow \mathrm{EP}$ & 0.216 & 0.087 & 0.129 & 0.146 \\
\hline $\mathrm{RS} \rightarrow \mathrm{ES}$ & 0.019 & -0.047 & 0.066 & 0.270 \\
\hline $\mathrm{AC} \rightarrow \mathrm{ES}$ & 0.280 & 0.265 & 0.014 & 0.464 \\
\hline $\mathrm{AT} \rightarrow \mathrm{ES}$ & 0.316 & 0.134 & 0.182 & 0.061 \\
\hline $\mathrm{EI} \rightarrow \mathrm{ES}$ & 0.010 & 0.056 & 0.046 & 0.666 \\
\hline $\mathrm{EP} \rightarrow \mathrm{ES}$ & 0.339 & 0.395 & 0.056 & 0.699 \\
\hline Marital Status (Largest Two Groups) & $\begin{array}{l}\text { Single } \\
(\text { Beta })\end{array}$ & $\begin{array}{c}\text { Married } \\
(\text { Beta })\end{array}$ & $\begin{array}{l}\text { Single-Married } \\
(\text { Beta })\end{array}$ & $\begin{array}{l}\text { Single-Married } \\
(p \text { Value })\end{array}$ \\
\hline $\mathrm{RS} \rightarrow \mathrm{EP}$ & 0.265 & 0.163 & 0.102 & 0.284 \\
\hline $\mathrm{AC} \rightarrow \mathrm{EP}$ & -0.151 & 0.200 & 0.351 & 0.931 \\
\hline $\mathrm{AT} \rightarrow \mathrm{EP}$ & 0.388 & 0.013 & 0.376 & 0.029 \\
\hline $\mathrm{EI} \rightarrow \mathrm{EP}$ & 0.091 & 0.152 & 0.061 & 0.647 \\
\hline $\mathrm{RS} \rightarrow \mathrm{ES}$ & 0.366 & -0.039 & 0.405 & 0.030 \\
\hline $\mathrm{AC} \rightarrow \mathrm{ES}$ & 0.033 & 0.302 & 0.270 & 0.912 \\
\hline $\mathrm{AT} \rightarrow \mathrm{ES}$ & 0.021 & 0.192 & 0.171 & 0.820 \\
\hline $\mathrm{EI} \rightarrow \mathrm{ES}$ & 0.295 & 0.054 & 0.241 & 0.118 \\
\hline $\mathrm{EP} \rightarrow \mathrm{ES}$ & 0.230 & 0.383 & 0.152 & 0.821 \\
\hline Education (Largest Two Groups) & Secondary School (Beta) & STPM/Diploma (Beta) & $\begin{array}{l}\text { Secondary School-STPM/Diploma } \\
(\text { Beta) }\end{array}$ & $\begin{array}{l}\text { Secondary School-STPM/Diploma } \\
\text { ( } p \text { Value })\end{array}$ \\
\hline $\mathrm{RS} \rightarrow \mathrm{EP}$ & 0.070 & 0.217 & 0.147 & 0.787 \\
\hline $\mathrm{AC} \rightarrow \mathrm{EP}$ & 0.289 & -0.012 & 0.301 & 0.085 \\
\hline $\mathrm{AT} \rightarrow \mathrm{EP}$ & 0.015 & 0.272 & 0.257 & 0.963 \\
\hline $\mathrm{EI} \rightarrow \mathrm{EP}$ & 0.149 & 0.057 & 0.091 & 0.275 \\
\hline $\mathrm{RS} \rightarrow \mathrm{ES}$ & 0.021 & -0.122 & 0.142 & 0.166 \\
\hline $\mathrm{AC} \rightarrow \mathrm{ES}$ & 0.298 & 0.136 & 0.163 & 0.185 \\
\hline $\mathrm{AT} \rightarrow \mathrm{ES}$ & 0.244 & 0.195 & 0.048 & 0.366 \\
\hline $\mathrm{EI} \rightarrow \mathrm{ES}$ & 0.007 & 0.150 & 0.143 & 0.849 \\
\hline $\mathrm{EP} \rightarrow \mathrm{ES}$ & 0.345 & 0.480 & 0.135 & 0.824 \\
\hline
\end{tabular}

Notes: Responsibility (RS), Accountability (AC), Analytical thinking (AT), Emotional intelligence (EI), Micro-Enterprise performance (EP), Micro-Enterprise sustainability (ES). Source: Author(s) own compilation. 


\section{Discussion}

The aspects of sustainability, expansion of operations, and survival of SMEs highly depend on certain skill sets of their principals [4]. As such, this work empirically investigated several essential effects of entrepreneurial leadership (i.e., responsibility, accountability, analytical thinking, and emotional intelligence) on enterprise performance and sustainability among micro-enterprises in Kelantan, Malaysia. The study outcomes revealed that the aspect of responsibility exerted by low-income household heads has a significantly positive effect upon their enterprise performance. This result is in line with Omerzel and Antoncic [38], who advocated that responsibility among entrepreneurs is indeed a leadership capability that facilitates achievement of superior performance among micro-enterprises in Kelantan, Malaysia.

The study also discovered a significantly positive effect of accountability among low-income household heads on their micro-enterprise performance and sustainability in Kelantan, Malaysia. This result is in agreement with prior studies cf. [43,92], therefore indicating that accountability is a crucial determinant that promotes not only the performance but also the sustainability of every firm. As for analytical thinking, this study discovered a significantly positive effect on micro-enterprise sustainability owned by low-income household heads in Kelantan, Malaysia. This outcome empirically supports the findings reported in prior studies [58-60] portraying that analytical thinking, in particular, as an entrepreneurial leadership trait, facilitates micro-enterprise sustainability.

In terms of emotional intelligence, the results display a significantly positive effect on micro-enterprise performance, which seems to be in concert with the results reported by Zampetakis et al. [68], hence supporting that emotional intelligence among low-income entrepreneurs enables them to achieve superior micro-enterprise performance in Kelantan, Malaysia. Lastly, this study revealed a significantly positive effect of micro-enterprise performance on micro-enterprise sustainability. This finding appears to be in line with Mishra and Suar [74], while extending empirical support towards the recent review made by Goyal and Rahman [72], thus confirming a positively significant influence of a micro-enterprise's performance on its sustainability in Kelantan, Malaysia.

Finally, as for mediating effects, the results exhibit significantly indirect effects of responsibility, analytical thinking, and emotional intelligence on enterprise sustainability, which ratify the mediating role of enterprise performance for correlations between entrepreneurial leadership traits (i.e., responsibility, analytical thinking, and emotional intelligence) and micro-enterprise sustainability among micro-enterprises owned by low-income household heads in Kelantan, Malaysia.

\section{Implications and Conclusions}

Small firms, such as micro-enterprises, cater to large communal groups apart from playing an important role as a powerful tool to combat poverty and to empower low-income households economically. As these firms appear to rely heavily on the resources of owners' characteristics and skills, this particular study investigated the effect of a significant human factor, which is entrepreneurial leadership (i.e., responsibility, accountability, analytical thinking, and emotional intelligence), on the performance and the sustainability of micro-enterprises in Kelantan, Malaysia so as to address several significant gaps found in the entrepreneurial literature and practice of micro-enterprises. In conclusion, this study is in agreement with Mindt and Rieckmann [93], who promulgated that the development of sustainability-driven enterprises seeks competent owners. Theoretically, the contribution of this study is in the form of empirical evidence that ratifies and extends the adoption of the RBV theory in examining the effects of several entrepreneurial leadership traits (i.e., responsibility, analytical thinking, and emotional intelligence) upon enterprise performance and sustainability among selected micro-enterprises in Kelantan, Malaysia. Based on the extensive review of literature, this appears to be the first study that employed large-scale primary data to examine and to provide empirical support for correlations between responsibility, accountability, analytical thinking, emotional intelligence, micro-enterprise performance, and micro-enterprise sustainability, within the context of emerging economies, using micro-enterprises in Kelantan, Malaysia as its data source. 
From the conceptual perspective, this study contributes crucially towards the Resource-Based View theory from the stance of small firms. This is performed by theorizing and providing empirical evidence that acquiring, deploying, and leveraging the identified dimensions of entrepreneurial leadership, such as firm-specific internal competencies, does not only positively affect enterprise performance but also further facilitates enterprise sustainability (i.e., economic, social, and environmental). Therefore, this study fulfils the ultimate purpose of the theory towards attaining sustainable competitive advantage (sustainability). In terms of novelty, this study uniquely contributes towards the body of knowledge by evaluating both the direct and indirect effects of responsibility, accountability, analytical thinking, and emotional intelligence on micro-enterprise sustainability. Such an approach is indeed necessary to reveal latent and casual correlations between the constructs of interest. Moreover, such robust and rigorous analysis also has aided in determining the significant factors of superior firm performance and enterprise sustainability.

Although some outcomes of the study diverged from the ones presented in the hypotheses, overall, the study contributes significantly towards the body of knowledge. For instance, the results obtained from path analysis and mediation test convey that although the aspect of analytical thinking among low-income entrepreneurs seems not to significantly affect micro-enterprise performance, it possesses the ability to affect micro-enterprise sustainability both directly and indirectly in a significant manner. Moreover, responsibility appears to affect performance directly but sustainability indirectly, while accountability influences both performance and sustainability directly, and emotional intelligence with its impact on micro-enterprise performance directly, but sustainability indirectly, which is mediated through micro-enterprise performance. Such outcomes deepen one's understanding pertaining to entrepreneurial leadership traits as well as their impacts on enterprise performance and sustainability, thus simultaneously extending the scope of the theory and enhancing the existing literature.

Within the context of practical implications, the outcomes of this study forward insights into the focus areas so as to improve micro-enterprise performance and sustainability, which appears to be crucial to promote entrepreneurial activities and to enhance the socio-economic conditions of highly vulnerable low-income households in emerging economies, such as that in Malaysia. In general, the outcomes retrieved from this study can be applied to other emerging or developed nations, where SMEs represent the majority of firms and where entrepreneurial leadership might as well have a significant impact on the performance and sustainability of firms. Specifically, these results can be applied by policymakers to sustainably address economical vulnerability among low-income households, particularly those residing at coastal Malaysia. In terms of micro-enterprise owners, this study highlights solid insights pertaining to the aspect of self-potential embedded amongst entrepreneurs, which could be further enhanced and translated to better micro-enterprise performance and sustainability, which, in turn, decreases the dependency of micro-entrepreneurs on external agencies, such as the government.

Based on these findings, both the government and the socio-economic developmental organizations should place more focus on enhancing leadership traits among low-income entrepreneurs, such as responsibility, accountability, analytical thinking, and emotional intelligence, by means of relevant policies. Such initiatives may enhance both the performance and sustainability of micro-enterprises, thus encouraging poor household heads to engage in additional entrepreneurial activities.

As for limitations, this study admits the possible influence of other factors upon micro-enterprise performance and sustainability that are not accommodated in the present model. Moreover, the focus of this study on a specific firm size from a single state in Malaysia suggests limited generalizability of its findings. Hence, it is recommended that future studies should integrate new relevant constructs into the present model so as to unravel deeper the aspects of entrepreneurial leadership, firm performance, and sustainability interplay. Furthermore, future endeavours could adopt the present model to examine the sustainable performance of small, medium, or large firms across nations, which would determine the applicability or the inability of this model to investigate sustainable performance across the globe. 
Author Contributions: A.A.M. conceptualized, develops the questionnaire, analyzed the data and review and editing this paper; S.A.F. designed the questionnaire; M.D.I. did the project administration and funding acquisition; M.D.I., M.N.H.B.Y. and S.A.F. contributed developing the research model, literature review, sample selection, data collection and preparing the manuscript.

Funding: This research was funded by the Ministry of Higher Education, Malaysia under the grant entitled "Developing a Comprehensive Rural Entrepreneurship Model for Poverty Eradication (REMODE)" (R/NRGS/A01.00/00047A/006/2014/000149).

Conflicts of Interest: The authors declare no conflict of interest.

\section{Appendix A. Survey Instrument}

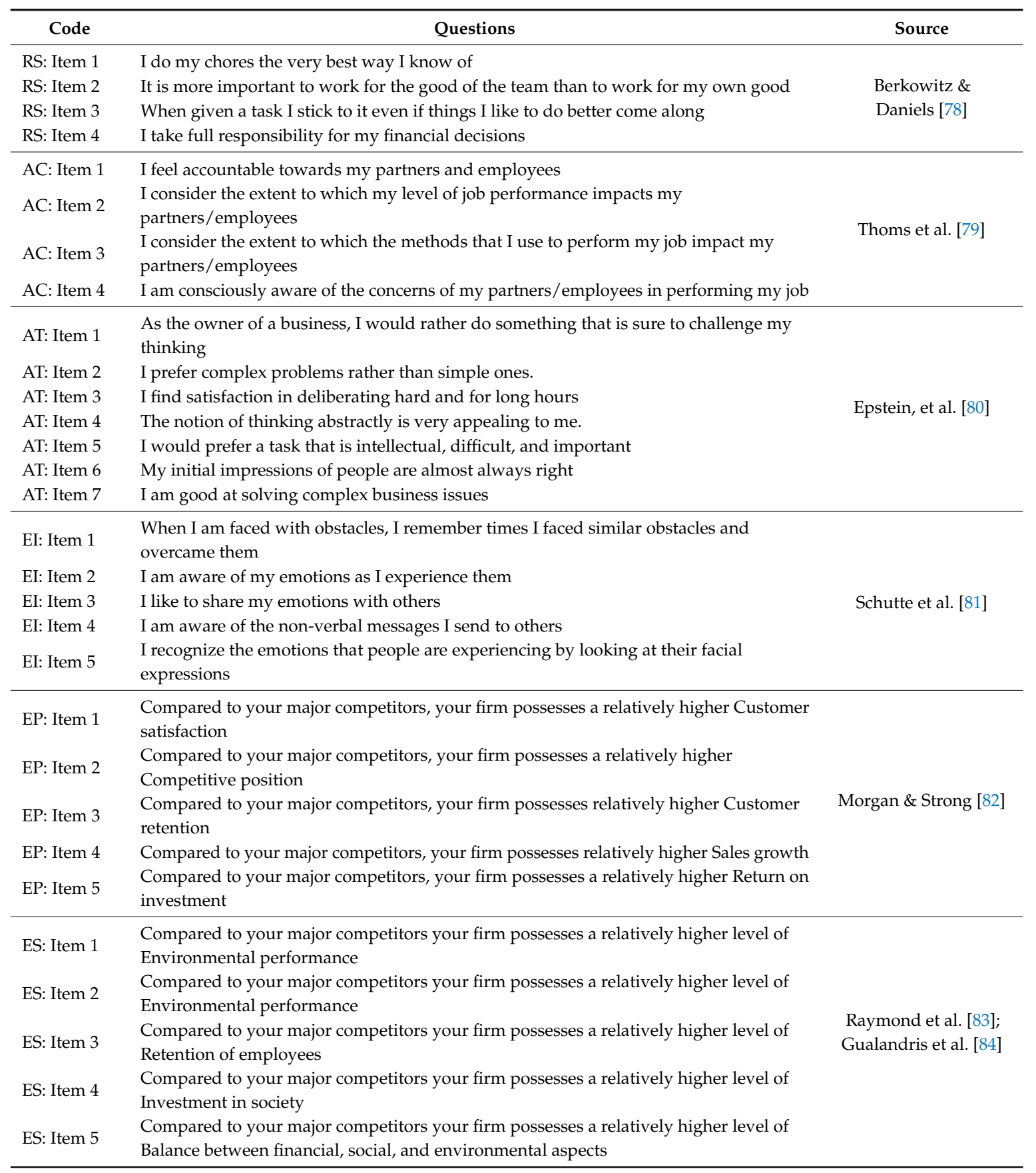




\section{References}

1. Amran, A.; Lee, S.P.; Devi, S.S. The influence of governance structure and strategic corporate social responsibility toward sustainability reporting quality. Bus. Strategy Environ. 2014, 23, 217-235. [CrossRef]

2. Gure, A.K.; Karugu, J. Strategic management practices and performance of small and micro enterprises in Nairobi City County, Kenya. Int. Acad. J. Hum. Resour. Bus. Adm. 2018, 3, 1-26.

3. Lateh, M.; Hussain, M.D.; Halim, M.S.A. Micro Enterprise Development and Income Sustainability for Poverty Reduction: A Literature Investigation. Int. J. Bus. Technopreneurship 2017, 7, 23-38.

4. Rahman, Z. The difficulties faced by micro and small enterprises in the formal market access: The case in small and micro enterprises in the cities of Makassar and Kabupaten Gowa south Sulawesi. Int. J. Humanit. 2016, 4, 92-103.

5. Nabiswa, F.; Mukwa, J.S. Impact of credit financing on human resource development among micro and small enterprises: A case study of Kimilili Sub County, Kenya. Asian J. Manag. Sci. Econ. 2017, 4, 43-53.

6. Al-Mamun, A.; Nawi, N.B.C.; Zainol, N.R.B. Entrepreneurial Competencies and Performance of Informal Micro-Enterprises in Malaysia. Mediterr. J. Soc. Sci. 2016, 7, 273-281. [CrossRef]

7. Aziz, N.N.A.; Halim, R.A.; Wahid, N.A. Networking and Innovation Performance in Micro-Enterprise in Malaysia. Adv. Sci. Lett. 2017, 23, 7374-7377. [CrossRef]

8. Eijdenberg, E.L.; Masurel, E. Entrepreneurial motivation in a least developed country: Push factors and pull factors among MSEs in Uganda. J. Enterp. Cult. 2013, 21, 19-43. [CrossRef]

9. Hameed, W.U.; Azeem, M.; Basheer, M.F.; Arif, M.; Hussain, T. Combination of Microcredit and Micro-Training with Mediating Role of Formal Education: A Micro-Enterprise Success Formula. J. Bus. Soc. Rev. Emerg. Econ. 2017, 3, 319-325. [CrossRef]

10. Beattie, S. Which Entrepreneurial Traits are the Most Critical in Determining Success? Otago Manag. Grad. Rev. 2016, 14, 13-20.

11. Odhiambo, A.A. Factors influencing performance of youth owned micro, small and medium enterprises in Kenya. Int. J. Soc. Sci. Entrep. 2013, 1, 263-272.

12. Renko, M.; El-Tarabishy, A.; Carsrud, A.L.; Brännback, M. Understanding and measuring entrepreneurial leadership style. J. Small Bus. Manag. 2015, 53, 54-74. [CrossRef]

13. Lubis, R.L. Assessing entrepreneurial leadership and the law: Why are these important for graduate students in Indonesia? Int. J. Arts Sci. 2017, 10, 41-76.

14. Cogliser, C.C.; Brigham, K.H. The Intersection of Leadership and Entrepreneurship: Mutual Lessons to Be Learned. Leadersh. Q. 2004, 15, 771-799. [CrossRef]

15. Webb, J.W.; Bruton, G.D.; Tihanyi, L.; Ireland, R.D. Research on entrepreneurship in the informal economy: Framing a research agenda. J. Bus. Ventur. 2013, 28, 598-614. [CrossRef]

16. Wahid, N.A.; Aziz, N.N.A.; Halim, R.A. Networking and Innovation Performance of Micro-Enterprises in Malaysia: The Moderating Effects of Geographical Location. Perrtanika J. Soc. Sci. Hum. 2017, 25, 281-292.

17. Barney, J. Firm resources and sustained competitive advantage. J. Manag. 1991, 17, 99-120. [CrossRef]

18. Todorovic, Z.W.; Schlosser, F.K. An entrepreneur and a leader! A framework conceptualizing the influence of leadership style on a firm's entrepreneurial orientation-performance relationship. J. Small Bus. Entrep. 2007, 20, 289-307. [CrossRef]

19. Lerner, M.; Almor, T. Relationships among strategic capabilities and the performance of women-owned small ventures. J. Small Bus. Manag. 2002, 40, 109-125. [CrossRef]

20. Grant, R.M. The resource-based theory of competitive advantage: Implications for strategy formulation. Calif. Manag. Rev. 1991, 33, 114-135. [CrossRef]

21. Ravichandran, T.; Lertwongsatien, C.; Lertwongsatien, C. Effect of information systems resources and capabilities on firm performance: A resource-based perspective. J. Manag. Inf. Syst. 2005, 21, 237-276. [CrossRef]

22. Wernerfelt, B. A resource-based view of the firm. Strateg. Manag. J. 1984, 5, 171-180. [CrossRef]

23. Yukl, G. Leadership in Organizations; Prentice Hall: Upper Saddle River, NJ, USA, 2008.

24. Becherer, R.C.; Mendenhall, M.E.; Eickhoff, K.F. Separated at Birth: An Inquiry on the Conceptual Independence of the Entrepreneurship and the Leadership Constructs. N. Engl. J. Entrep. 2008, 11, 13-27. [CrossRef] 
25. Stogdill, R.M. Personal Factors Associated with Leadership: A Survey of the Literature. J. Psychol. 1948, 25, 35-71. [CrossRef] [PubMed]

26. Natuna, D.A.; Rinaldi, R. The Competency of Teacher Entrepreneurship in Teaching. Int. J. Econ. Bus. Appl. 2017, 2, 41-52.

27. Greenberg, D.; McKone-Sweet, K.; Wilson, H.J. The New Entrepreneurial Leader: Developing Leaders Who Shape Social and Economic Opportunity; Berrett-Koehler Publishers: Oakland, CA, USA, 2011.

28. Man, T.W.; Lau, T.; Snape, E. Entrepreneurial competencies and the performance of small and medium enterprises: An investigation through a framework of competitiveness. J. Small Bus. Entrep. 2008, 21, 257-276. [CrossRef]

29. Daily, C.M.; Patricia, P.M.; Covin, J.G.; Dalton, D.R. Governance and Strategic Leadership in Entrepreneurial Firms. J. Manag. 2002, 28, 387-412. [CrossRef]

30. Frank, H.; Lueger, M.; Korunka, C. The significance of personality in business start-up intentions, start-up realization and business success. Entrep. Region. Dev. 2007, 19, 227-251. [CrossRef]

31. Venkatraman, N.; Ramanujam, V. Measurement of business performance in strategy research: A comparison of approaches. Acad. Manag. Rev. 1986, 11, 801-814. [CrossRef]

32. Burnard, K.; Bhamra, R. Organizational resilience: Development of a conceptual framework for organizational responses. Int. J. Prod. Res. 2011, 49, 5581-5599. [CrossRef]

33. Naffziger, D. Entrepreneurship: A person based theory approach. Adv. Entrep. Firm Emerg. Growth 1995, 2, 21-50.

34. Zhao, H.; Seibert, S.E. The big five personality dimensions and entrepreneurial status: A meta-analytical review. J. Appl. Psychol. 2006, 91, 259-271. [CrossRef] [PubMed]

35. Kuratko, D.F. Entrepreneurial leadership in the 21st century: Guest editor's perspective. J. Leadersh. Org. Stud. 2007, 13, 1-11. [CrossRef]

36. Rodríguez, F.J.G.; Cruz, Y.D.M. A. Relation between social-environmental responsibility and performance in hotel firms. Int. J. Hosp. Manag. 2007, 26, 824-839. [CrossRef]

37. Benavides-Velasco, C.A.; Quintana-García, C.; Marchante-Lara, M. Total quality management, corporate social responsibility and performance in the hotel industry. Int. J. Hosp. Manag. 2014, 41, 77-87. [CrossRef]

38. Omerzel, D.G.; Antoncic, B. Critical entrepreneur knowledge dimensions for the SME performance. Ind. Manag. Data Syst. 2008, 108, 1182-1199. [CrossRef]

39. Searcy, C. Measuring Enterprise Sustainability. Bus. Strategy Environ. 2016, 25, 120-133. [CrossRef]

40. Parrish, B.D. Sustainability-driven entrepreneurship: Principles of organization design. J. Bus. Ventur. 2010, 25, 510-523. [CrossRef]

41. Hall, A.T.; Blass, F.R.; Ferris, G.R.; Massengale, R. Leader reputation and accountability in organizations: Implications for dysfunctional leader behavior. Leadersh. Q. 2004, 15, 515-536. [CrossRef]

42. Tan, H.T.; Kao, A. Accountability effects on auditors' performance: The influence of knowledge, problem-solving ability, and task complexity. J. Account. Res. 1999, 37, 209-223. [CrossRef]

43. Nuhu, M.; Hussani, S.M. Empirical Study of the Relationship between Board of Director Mechanisms and Perceived Performance of Listed Firms in Nigeria. J. Account. Financ. Emerg. Econ. 2017, 3, 149-168. [CrossRef]

44. Kobuthi, E.; K'Obonyo, P.; Ogutu, M. Corporate Governance and Performance of Firms Listed on the Nairobi Securities Exchange. Int. J. Sci. Res. Manag. 2018, 6, 7-17. [CrossRef]

45. Rimvydas, L. Key Features of Sustainable Universities: A Literature review. J. Bus. Manag. 2017, 13, 56-69.

46. Jamali, D. Insights into triple bottom line integration from a learning organization perspective. Bus. Process Manag. J. 2006, 12, 809-821. [CrossRef]

47. Gray, R.; Adams, C.; Owen, D. Accountability, Social Responsibility and Sustainability: Accounting for Society and the Environment; Pearson Higher Education: London, UK, 2014.

48. Adams, C.A.; McNicholas, P. Making a difference: Sustainability reporting, accountability and organisational change. Account. Audit. Account. 2007, 20, 382-402. [CrossRef]

49. Perego, P.; Kolk, A. Multinationals' accountability on sustainability: The evolution of third-party assurance of sustainability reports. J. Bus. Ethics 2012, 110, 173-190. [CrossRef]

50. Ricketts, J.C.; Rudd, R.D. Critical thinking skills of selected youth leaders: The efficacy of critical thinking dispositions, leadership, and academic performance. J. Agric. Educ. 2005, 46, 32-43. [CrossRef] 
51. Flores, K.L.; Matkin, G.S.; Burbach, M.E.; Quinn, C.E.; Harding, H. Deficient critical thinking skills among college graduates: Implications for leadership. Educ. Philos. Theory 2012, 44, 212-230. [CrossRef]

52. Elson, S.B.; Hartman, R.; Beatty, A.; Trippe, M.; Buckley, K.; Bornmann, J.; Servi, L. Critical Analytic Thinking Skills: Do They Predict Job-Related Task Performance Above and Beyond General Intelligence? Pers. Assess. Decis. 2018, 4, 9-29. [CrossRef]

53. Drath, W.H. Managerial Strengths and Weaknesses as Functions of the Development of Personal Meaning. J. Appl. Behav. Sci. 1990, 26, 483-499. [CrossRef]

54. Ibdah, $\mathrm{K}$. The effect of strategic thinking patterns on the efficiency of decision-making process in Jordanian companies of insurance. Arch. Bus. Res. 2018, 6, 67-93. [CrossRef]

55. Kealey, B.T.; Holland, J.; Watson, M. Preliminary evidence on the association between critical thinking and performance in principles of accounting. Issues Account. Educ. 2005, 20, 33-49. [CrossRef]

56. Thomas, I. Critical thinking, transformative learning, sustainable education, and problem-based learning in universities. J. Transform. Edu. 2009, 7, 245-264. [CrossRef]

57. Almeida, H.; Santos, C.; Albuquerque, C. Social Entrepreneurship and Innovation. Osmosis between social and market based principles? In Proceedings of the 1st Annual ACRN Conference on Social-Entrepreneurship Perspectives, Linz, Austria, 21-26 August 2011.

58. Bradley, S.P.; Nolan, R.L. Sense and Respond: Capturing Value in the Network Era; Harvard Business School Press: Boston, MA, USA, 1998.

59. Markides, C.C. All the Right Moves: A Guide to Crafting Breakthrough Strategy; Harvard Business School Press: Boston, MA, USA, 2000.

60. Liu, Y. Sustainable competitive advantage in turbulent business environments. Int. J. Prod. Res. 2013, 51, 2821-2841. [CrossRef]

61. Menzel, S. Are emotions to blame? The impact of non-analytical information processing on decision-making and implications for fostering sustainability. Ecol. Econ. 2013, 96, 71-78. [CrossRef]

62. Salovey, P.; Mayer, J.D. Emotional intelligence. Imagin. Cogn. Pers. 1990, 9, 185-211. [CrossRef]

63. Anyanwu, C.; Oad, S. Entrepreneurial Leadership and Organizational Creativity in the Collectivist Context: The moderating role of Emotional Intelligence. Int. J. Manag. Adm. Sci. 2016, 4, 1-12.

64. Caruso, D.R.; Mayer, J.D.; Salovey, P. Emotional intelligence and emotional leadership. In Proceedings of the Kravis-De Roulet Leadership Conference, Claremont McKenna Coll, Claremont, CA, USA, 22-23 February 2002.

65. Duckett, H.; Macfarlane, E. Emotional intelligence and transformational leadership in retailing. Leadersh. Org. Dev. J. 2003, 24, 309-317. [CrossRef]

66. Petrides, K.V.; Furnham, A. Trait emotional intelligence: Psychometric investigation with reference to established trait taxonomies. Eur. J. Pers. 2001, 15, 425-448. [CrossRef]

67. Nanayakkara, S.M.; Wickramasinghe, V.; Samarasinghe, G.D. Emotional intelligence, technology strategy and firm's non-financial performance. In Proceedings of the Engineering Research Conference (MERCon), Moratuwa, Sri Lanka, 29-31 May 2017; pp. 467-472.

68. Zampetakis, L.A.; Beldekos, P.; Moustakis, V.S. “Day-to-day” entrepreneurship within organisations: The role of trait Emotional Intelligence and Perceived Organizational Support. Eur. Manag. J. 2009, 27, 165-175. [CrossRef]

69. Heffernan, T.; O’Neill, G.; Travaglione, T.; Droulers, M. Relationship marketing: The impact of emotional intelligence and trust on bank performance. Int. J. Bank Mark. 2008, 26, 183-199. [CrossRef]

70. Aslam, S.; Shahid, M.N.; Qureshi, M.H.; Qureshi, A.M. Investigating Innovativeness and Emotional Intelligence as Mediator to Explore Enterprenurial Marketing Strategy Focused on Firm Performance: A Case in Pakistan. J. Appl. Environ. Biol. Sci. 2018, 8, 48-60.

71. Weinberger, L.A. Emotional intelligence, leadership style, and perceived leadership effectiveness. Adv. Dev. Hum. Resour. 2009, 11, 747-772. [CrossRef]

72. Goyal, P.; Rahman, Z. Corporate sustainability performance and firm performance association: A literature review. Int. J. Sustain. Strateg. Manag. 2014, 4, 287-308. [CrossRef]

73. Humphrey, N.; Curran, A.; Morris, E.; Farrell, P.; Woods, K. Emotional intelligence and education: A critical review. Educ. Psychol. 2007, 27, 235-254. [CrossRef]

74. Mishra, S.; Suar, D. Does corporate social responsibility influence firm performance of Indian companies? J. Bus. Ethics 2010, 95, 571-601. [CrossRef] 
75. López, M.V.; Garcia, A.; Rodriguez, L. Sustainable development and corporate performance: A study based on the Dow Jones sustainability index. J. Bus. Ethics 2007, 75, 285-300. [CrossRef]

76. Jacobs, B.W.; Singhal, V.R.; Subramanian, R. An empirical investigation of environmental performance and the market value of the firm. J. Oper. Manag. 2010, 28, 430-441. [CrossRef]

77. Reinartz, W.; Haenlein, M.; Henseler, J. An empirical comparison of the efficacy of covariance-based and variance-based SEM. Int. J. Res. Mark. 2009, 26, 332-344. [CrossRef]

78. Berkowitz, L.; Daniels, L.R. Affecting the salience of the social responsibility norm: Effects of past help on the response to dependency relationships. J. Abnorm. Soc. Psych. 1964, 68, 275-281. [CrossRef]

79. Thoms, P.; Dose, J.J.; Scott, K.S. Relationships between accountability, job satisfaction, and trust. Hum. Resour. Dev. Q. 2002, 13, 307-323. [CrossRef]

80. Epstein, S.; Pacini, R.; Denes-Raj, V.; Heier, H. Individual differences in intuitive-experiential and analytical-rational thinking styles. J. Pers. Soc. Psychol. 1996, 71, 390-405. [CrossRef] [PubMed]

81. Schutte, N.S.; Malouff, J.M.; Hall, L.E.; Haggerty, D.J.; Cooper, J.T.; Golden, C.J.; Dornheim, L. Development and validation of a measure of emotional intelligence. Pers. Indiv. Differ. 1998, 25, 167-177. [CrossRef]

82. Morgan, R.E.; Strong, C.A. Business performance and dimensions of strategic orientation. J. Bus. Res. 2003, 56, 163-176. [CrossRef]

83. Raymond, L.; Marchand, M.; St-Pierre, J.; Cadieux, L.; Labelle, F. Dimensions of small business performance from the owner-manager's perspective: A re-conceptualization and empirical validation. Entrep. Reg. Dev. 2013, 25, 468-499. [CrossRef]

84. Gualandris, J.; Golini, R.; Kalchschmidt, M. Do supply Management and global sourcing matter for firm sustainability performance? An international study. Supply Chain Manag. 2014, 19, 258-274. [CrossRef]

85. Podsakoff, P.M.; MacKenzie, S.B.; Lee, J.Y.; Podsakoff, N.P. Common method biases in behavioral research: A critical review of the literature and recommended remedies. J. Appl. Psychol. 2003, 88, 879-903. [CrossRef] [PubMed]

86. Harman, H.H. Modern Factor Analysis; University of Chicago Press: Chicago, IL, USA, 1976.

87. Bagozzi, R.P.; Yi, Y.; Phillips, L.W. Assessing construct validity in organizational research. Adm. Sci. Q. 1991, 36, 421-458. [CrossRef]

88. Hair, J.F.; Ringle, C.M.; Sarstedt, M. PLS-SEM: Indeed a silver bullet. J. Mark. Theory Pract. 2011, 19, 139-152. [CrossRef]

89. Hair, J.F.; Ringle, C.M.; Sarstedt, M. Partial least squares structural equation modeling: Rigorous applications, better results and higher acceptance. Long Range Plan. 2013, 46, 1-12. [CrossRef]

90. Diamantopoulos, A.; Siguaw, J.A. Formative versus reflective indicators in organizational measure development: A comparison and empirical illustration. Br. J. Manag. 2006, 17, 263-282. [CrossRef]

91. Chin, W.W. The partial least squares approach to structural equation modeling. Mod. Methods Bus. Res. 1998, 295, 295-336.

92. Keay, A.R. Board Accountability and the Entity Maximization and Sustainability Approach. In Understanding the Company: Corporate Governance and Theory; Choudhury, B., Petrin, M., Eds.; Cambridge University Press: Cambridge, UK, 2016.

93. Mindt, L.; Rieckmann, M. Developing competencies for sustainability-driven entrepreneurship in higher education: A literature review of teaching and learning methods. Teoría de la Educ. Rev. Interuniv. 2017, $29,129-159$.

(C) 2018 by the authors. Licensee MDPI, Basel, Switzerland. This article is an open access article distributed under the terms and conditions of the Creative Commons Attribution (CC BY) license (http:/ / creativecommons.org/licenses/by/4.0/). 